\title{
Seeding Indian ricegrass in an arid environ- ment in the Great Basin
}

\author{
JAMES A. YOUNG, ROBERT R. BLANK, WILLIAM S. LONGLAND, AND DEBRA E. \\ PALMQUIST
}

Authors are range scientist, soil scientist, animal ecologist, and mathematician/statistician, respectively, USDAARS, 920 Valley Road. Reno. Nev. 89512.

\begin{abstract}
Indian ricegrass [Oryzopsis hymenoides (R. \& S.) Ricker] is a valuable forage species adapted to arid rangelands in temperate deserts. The purpose of this study was to test the influence of seeding date, depth, and rate on Indian ricegrass emergence and seedling establishment of acid scarified and intact caryopses (seeds). The seeding experiments were conducted on a wind eroding sand sheet of Lahontan age in western Nevada. During the initial year of planting, seeds of the cultivars Nezpar and Paloma Indian ricegrass were successfully established without pretreatment by acid scarification. Acid scarified seeds did not result in the established seedling stands in the field. Initial seedings were done in a season with prolonged moisture events with total precipitation about twice the average. Seedling stands of crested wheatgrass [Agropyron desertorum (Fisch.) ex Link Schult] as well as other exotic and native herbaceous and woody species were established during the first year. During the next 4 years crested wheatgrass seedlings were never again established. Indian ricegrass seedlings were established in 3 of the $\mathbf{4}$ subsequent years of seeding trials using a seeding rate of 0.8 seeds/cm of row and a seeding depth of 1 $\mathrm{cm}$. Indian ricegrass seedling emergence was increased by either increasing the planting depth to $5 \mathrm{~cm}$ or by reducing the seeding rate to $0.03 \mathrm{seeds} / \mathrm{cm}$ of row. The ultra-low seeding rate resulted in a significant saving in seed cost.
\end{abstract}

Key Words: arid revegetation, seed and seedbed ecology, seeding depth and seeding rate

Indian ricegrass [Oryzopsis hymenoides (R. \& S.) Ricker] occurs in 17 western states of the United States, the southern Canadian provinces, and Mexico (Hitchcock 1950). From the sandhills of Nebraska, through the mixed prairies, to the desert grasslands of the Southwest, Indian ricegrass is an important forage species on rangelands (Robertson 1976). In the Great Basin, Indian ricegrass occurs in a number of communities over an extremely wide range of elevation and soil types (Young et al. 1976). It grows in the lower portions of the basins of northern Nevada where extensive areas of sand occur. The Carson Desert of western Nevada has many examples of extensive landscapes where the dominant herbaceous vegetation, and nearly the only perennial grass species, is Indian ricegrass (Billings 1949). A winter livestock grazing system was developed to utilize the Indian ricegrass resource in the deserts of Nevada (Young and Sparks 1985).

The numerous basins of the Great Basin filled with water during the Pleistocene at the same time mountain glaciers advanced (Russell 1885). Several of the basins spilled together to form, in northwestern Nevada and portions of northeastern California, a gigantic inland sea known as pluvial Lake Lahontan. Pluvial is a geologic

Manuscript accepted 12 Jun. 1993. term referring to former wetter times. Lake Lahontan received water from 5 glacially fed rivers. From the Sierra Nevada came the Susan, Truckee, Carson, and Walker rivers. From the central and northern highlands of the Great Basin came the Humboldt River. Where the rivers entered the deep waters of Lake Lahontan they left coarse textured deltas. During the Holocene the lakes have almost entirely dried, exposing the coarse textured sediments to wind erosion. The combination of low and high pressure wind circulation has driven these sediments to the northeast (Morrison 1964). Occasionally these sand deposits are largely bare, highly active dunes, but more typically they are more or less stabilized, shrub dominated landscapes. These are the landscapes where extensive stands of Indian ricegrass occur.

Range managers have long recognized that these Indian ricegrass dominated landscapes were a very valuable resource for winter grazing. Until recently, when grazing management systems were applied to these areas, very little range management was practiced. The sites were not subject to wildfires because of the lack of herbaceous vegetation for igniting and carrying fires. The sites were considered too arid for conventional seeding practices. During the 1980 s, the alien annual cheatgrass (Bromus tectorum L.) invaded a portion of these Indian ricegrass/shrub communities (Young and Tipton 1989). Cheatgrass became sufficiently abundant in basin big sagebrush (Artemisia tridentata ssp. tridentata Nutt.) communities so that during the mid 1980 s extensive areas burned in wildfires. Once the vegetation was destroyed by wildfires, the sands were subjected to very active wind erosion which posed a problem for highways, railroads, and urban areas as well as the range sites themselves.

At the time very little was known concerning post fire succession on these areas because extensive wildfires in these environments were virtually unknown. It appeared that artificial revegetation was required to stabilize these landscapes. Long-term precipitation records for the burned areas indicated annual averages of 12.5 to $15.0 \mathrm{~cm}$. Seeding of perennial grasses in the Great Basin has historically been restricted to areas with at least $25 \mathrm{~cm}$ of precipitation, with occasional attempts at as low as $20 \mathrm{~cm}$ (Young and McKenzie 1982).

The obvious perennial grass for seeding on these burned areas was Indian ricegrass. L.A. Stoddart experimented with Indian ricegrass in seeding trials in the 1930s (Stoddart and Wilkinson 1938), and considerable interest in using this species has been shown over the years (Plummer and Frischknecht 1952). The cultivars Nezpar and Paloma were developed by selection and released for use in range seedings (Anon. 1978, Booth et al. 1980). Indian ricegrass was only seeded on limited experimental areas on the large mid 1980s burns. Other species (which generally either failed to establish or persist) were seeded because of: (a) the prohibitive cost of Indian ricegrass seed, (b) limited supplies of seed of the 
species in the commercial trade, and (c) the general reputation that seed dormancy made it very difficult to establish Indian ricegrass stands.

There is a large amount of literature concerning the dormancy of Indian ricegrass seeds. It starts with M.Z. Huntamer (1934) and continues through the present (Blank and Young 1992). Generally, it is thought that the indurate lemma and palea of the caryopses limit germination and that in some seed sources embryo dormancy also exists (Toole 1940; Rogler 1960; Fendall 1964; Clark and Bass 1970; McDonald 1976; Shaw 1976; McDonald and Khan 1977; 1978, 1983; Zemetra et al. 1983; Young and Evans 1984). In nature, it has been determined that a major form of seedling recruitment is growth of plants from seeds in scatterhoard caches of rodents (McAdoo et al. 1983).

In 1985, with cooperation from the Bureau of Land Management, USDI, we initiated seeding trials on Lahontan sands near Flanigan, Nev. Our purpose is to report on a variety of experiments concerning the establishment of Indian ricegrass on Lahontan age sands in a temperate desert environment.

\section{Methods and Materials}

Field experiments were located about $100 \mathrm{~km}$ north of Reno, Nev., near the ghost town of Flanigan on the California-Nevada border. The site is located on a series of off-shore bar deposits created by pluvial Lake Lahontan. The lake beach topography is buried by water-rounded sands of apparent Lahontan age. The site is located on the northeastern edge of the Honey Lake embayment of Lake Lahontan, near Astor and Sand Passes where the embayment connected with the main lake. The sand sheet where the experiments were located apparently originated from the deltas of the Susan River and Long Valley Creek. Currently the sand sheet is being driven by prevailing winds up and over a series of mountainous ridges $(300$ to $500 \mathrm{~m}$ ) into Dry Valley and eventually to the Smoke Creek Desert. Sand depth varies from less than a meter to more than $10 \mathrm{~m}$. The soils at the study site are Xeric Torripsamments.

The area was burned in a large $(6,800 \mathrm{ha})$ wildfire in mid summer of 1985. The wildfires started in the uplands of Dry Valley in an area dominated by basin big sagebrush (Artemisia tridentata subsp. tridentata Nutt.) and cheatgrass vegetation. The fire was driven over the mountains and down into the Honey Lake basin by stiff north winds. This is a very atypical stand of basin big sagebrush, growing far below the normal big sagebrush zone, apparently as a result of the moisture available from the sands. The stand was dominated by mature to near senescent plants near $1 \mathrm{~m}$ in height with central trunks greater than $1 \mathrm{dm}$ in diameter. The fire consumed most of these large big sagebrush trunks to the sand surface. Smokebrush (Psorothamnus polydenius Rydb.) was an important woody component of these communities. Smokebrush is very unusual for big sagebrush communities in the Great Basin. Based on preburn range surveys by land management agencies and information from knowledgeable ranchers, Indian ricegrass was rare in the preburn community and the plants that did occur appeared senescent. This is the situation in portions of the community that were protected from burning by a road or fire lines. Plant communities immediately off the sand sheet, growing on fine textured soils derived from saline/alkaline lake sediments, support sparse shadscale (Atriplex confertifolia Torr. \& Frem.) or Bailey greasewood [Sarcobatus baileyi (Cov.) Jeps.] communities.

It is difficult to estimate the average long-term precipitation at the study site. Flanigan, Nev., was apparently never the site of an official weather station, but periodic records kept at the town site indicated between 10 and $12.5 \mathrm{~cm}$ of annual precipitation. Sandpass, Nev., at a slightly higher elevation, averaged about $15 \mathrm{~cm}$ and Nixon, Nev., near Pyramid Lake averages $13.8 \mathrm{~cm}$ (Anon. 1941).
The majority of the precipitation occurs during the winter as snow; however, an occasional high intensity summer thunderstorm can markedly influence annual precipitation at such sites where the total precipitation is so low. Precipitation during the study included a once in 60 to 80 year winter storm in February 1986 (Table 1).

Table 1. Annual precipitation by months, measured in rain gauge located at the Flanigan, Nev. experimental site.

\begin{tabular}{|c|c|c|c|c|c|c|}
\hline Month & $85-86$ & $86-87$ & $\begin{array}{c}\text { Year } \\
87-88\end{array}$ & $88-89$ & $89-90$ & Mean \\
\hline & \multicolumn{6}{|c|}{$-1,1(\mathrm{~cm}) \cdots$} \\
\hline Jul.-Aug. & 0 & 0.6 & 1.2 & 2.2 & 2.2 & 1.2 \\
\hline Sept. & 0 & 1.2 & 0 & 0.2 & 2.9 & 0.9 \\
\hline Oct. & 2.3 & 2.0 & 0 & 0.4 & 1.7 & 1.3 \\
\hline Nov. & 2.5 & 0 & 0.7 & 1.5 & 1.7 & 1.3 \\
\hline Dec. & 2.6 & 1.6 & 1.7 & 2.4 & 0 & 1.7 \\
\hline Jan. & 2.2 & 0.2 & 2.1 & 1.8 & 2.3 & 1.7 \\
\hline Feb. & 5.21 & 0.7 & 0.2 & 0 & 1.4 & 1.5 \\
\hline Mar. & 2.8 & 1.0 & 1.4 & 0 & 1.0 & 1.2 \\
\hline Apr. & 3.1 & 0.5 & 0.1 & 0 & 1.6 & 1.1 \\
\hline May & 0 & 1.5 & 0 & 0 & 1.0 & 0.5 \\
\hline Jun. & 0 & 0.2 & 0 & 0 & 0.5 & 0.1 \\
\hline Total & 20.7 & 9.5 & 7.4 & 8.5 & 16.3 & 12.5 \\
\hline
\end{tabular}

IEstimated as once in 60 to 80 year storm.

The area burned in the wildfire at Flanigan now supports a very diverse community of granivorous desert rodents of the family Heteromyidae, including 4 species of kangaroo rats (Dipodomys merriami, $D$. ordii, D. panamintinus, and $D$. deserti), and a pocket mouse (Perognathus longimembrims). The adjacent unburned plant community supports a much less diverse rodent community composed largely of $D$. merriami (unpublished research ARSUSDA, Reno, Nev.).

After the wildfire in 1985 we fenced a 1-ha area to exclude livestock and blacktailed jackrabbits (Lepus californicus). No other site preparation such as tillage was conducted before seeding. All seeding was done by hand in $3-\mathrm{m}$-long rows spaced $0.6 \mathrm{~m}$ apart. Seeds were initially planted $1.0-\mathrm{cm}$ deep at a rate of 1 seed per 1.25 $\mathrm{cm}$ of row. The experimental design consisted of 4 replications in a randomized block design. The first winter following the fire, seeding started in September and continued until the following May. Subsequently we seeded trials 4 times during each fall to spring from 1986-87 through 1989-90. These times were early fall (September), late fall (December), early spring (February), and late spring (March).

\section{Initial Trials}

Not being sure what was adapted to the site, we seeded a variety of species the first year. Besides Indian ricegrass we seeded 'Nordan' crested wheatgrass [Agropyron desertorum (Fish. ex Link) Schult], 'Hycrest' crested wheatgrass $(A$. desortorum (Fisch. ex Link) Schult $\times A$. cristatum (L.) Love], 'Greenar' intermediate wheatgrass (Thinopyrum intermedium (Host) Barkworth and D.R. Dewey], 'Appar' blue flax (Linum perenne ssp. lewisii (Pursh) Hult.], antelope bitterbrush [Purshia tridentata (Pursh) DC], and fourwing saltbush (Atriplex canescens (Pursh) Nutt.]. Seedling stands were evaluated in the fall (following planting) by counting the number of seedlings per meter of row.

\section{Preliminary Indian Ricegrass Experiments}

Based on previous research concerning Indian ricegrass emergence from Lahontan sands (Kinsinger 1962), we planted a trial with Nezpar Indian ricegrass where the treatments were planting depths of $1.0,5.0$, and $15.0 \mathrm{~cm}$. Sand from the study site was returned to the greenhouse and emergence trials were conducted 
with planting depths of $0,0.1,0.5$, and $1.0 \mathrm{~cm}$ and then at $1-\mathrm{cm}$ increments through $20 \mathrm{~cm}$. The trials were conducted in boxes on the top of greenhouse benches during November and December 1985. The procedures described by Young et al. (1969) were followed in preparing the soil in the boxes and planting the seeds. Emergence was recorded for 4 weeks. Greenhouse temperatures ranged from $15^{\circ} \mathrm{C}$ during the night to 20 to $25^{\circ} \mathrm{C}$ during the day.

During the winter of 1985-86 we planted seeds of Nezpar and Paloma Indian ricegrass that had been scarified with sulfuric acid following the procedures described by Young et al. (1985). Nezpar and Paloma Indian ricegrass seeds were treated for 15 and 30 minutes, respectively.

Based on the results obtained in 1985 we established 5 experiments that were repeated each year from 1986-87 to 1989-90. These experiments tested the effects of time of planting, depth of planting, and density of planting. Only 'Nezpar' Indian ricegrass was used. For comparisons, at each planting date 'Nordan' crested wheatgrass was planted at the rate of $1 \mathrm{seed} / 1.25 \mathrm{~cm}$ of row, with a planting depth of $1.25 \mathrm{~cm}$.

\section{Time of Planting}

The planting dates in each year of the experiments were early fall (September), late fall (December), early spring (February), and late spring (March).

\section{Depth of Planting}

The depths for the depth-of-planting experiment were 1.0, 2.5, 5.0 , and $15.0 \mathrm{~cm}$.

\section{Density of Planting}

The densities of planting $(1.0 \mathrm{~cm}$ depth) were $0.03,0.1,0.4$, and $0.8 \mathrm{seeds} / \mathrm{cm}$ of row with a $30-\mathrm{cm}$ row separation.

\section{Drill Experiment}

The results obtained by hand seeding were tested in 1987 with a tractor drawn drill. The site was on the Bird Flat Ranch north of Doyle, Calif. This site is the opposite side of Honey Lake Valley from the Flanigan experiments. The area burned in 1986 in a large wildfire. Preburn vegetation consisted of big sagebrush, desert peach (Prunus andersonii (Gray) and needle-and-threadgrass (Stipa comata Trin. and Rupr.). The sand textured soils were derived from decomposing granite with semi-angular particles rather than the water rounded sands of the Flanigan site. The soils of this site are Torripsammentic Haploxerolls. The drill used in this seeding had fluted disk openers followed by a double disk and a press wheel. The seeding rate was 0.03 seeds $/ \mathrm{cm}$ and the seeding depth $5 \mathrm{~cm}$.

An analysis of variance (ANOVA) was used on emergence data. An arcsin transformation was applied to stabilize unequal variance and a fourth-degree polynomial regression was fitted to analyze emergence by planting depth and planting rate.

\section{Results and Discussion}

\section{Initial Seeding 1985-86}

During the winter of $1985-86$ precipitation events started in October and continued through April, with a major storm during a 10-day period in February (Table 1). Virtually every species we planted germinated and emerged under these continuously moist, competition free conditions (Table 2). Generally, a crested wheatgrass stand in the $25-\mathrm{cm}$ precipitation area of the big sagebrush zone would be considered fully stocked with 3.25 plants $/ \mathrm{m}$ of row with $30-\mathrm{cm}$ row spacing. It was apparent that the stands obtained from the initial seedings at the Flanigan site exceeded these stocking standards. Establishment of the shrubs antelope bitterbrush and fourwing saltbush from direct seeding is difficult to obtain
Table 2. Seedlings per $\mathrm{m}$ of row for 4 planting dates during winter of 1985-86 at Flanigan, Nev.1

\begin{tabular}{|c|c|c|c|c|}
\hline \multirow[b]{3}{*}{ Species/cultivar } & \multicolumn{4}{|c|}{ Seedlings $/ \mathrm{m}$ of row } \\
\hline & \multicolumn{2}{|c|}{ Fall } & \multicolumn{2}{|c|}{ Spring } \\
\hline & Early & Late & Early & Late \\
\hline & \multicolumn{4}{|c|}{$\ldots-($ No. per $m$ row) $-\ldots$} \\
\hline \multicolumn{5}{|l|}{ Indian ricegrass } \\
\hline Nezpar & $8 b$ & $11 \mathrm{~b}$ & $17 a$ & $9 b$ \\
\hline Paloma & $8 b$ & $7 b$ & $16 a$ & $15 a$ \\
\hline \multicolumn{5}{|l|}{ Crested wheatgrass } \\
\hline Nordan & 15 & 18 & 14 & 17 \\
\hline Hycrest & 16 & 15 & 13 & 14 \\
\hline \multicolumn{5}{|c|}{ Intermediate wheatgrass } \\
\hline Greenar & 17 & 18 & 21 & 18 \\
\hline \multicolumn{5}{|l|}{ Blue flax } \\
\hline Appar & 8 & 9 & 11 & 12 \\
\hline Bitterbrush & 0.1 & 0.8 & 1.1 & 0 \\
\hline Fourwing saltbush & 1.1 & 1.5 & 3.2 & 1.4 \\
\hline
\end{tabular}

'For Nezpar and Paloma Indian ricegrass, seedling density means followed by the same letter are not significantly different at the 0.05 level of probability as determined by Duncan's Multiple Range Test. No significant differences among planting dates occurred for other species.

with consistency even in higher precipitation portions of the big sagebrush zone. Indian ricegrass seedling emergence was excellent at all planting dates during the first planting season. The area burned in the wildfire was subject to severe wind erosion during the winter of 1985-86. The major root systems of large big sagebrush plants were exposed as some areas deflated $1 \mathrm{~m}$ or more. The Lahontan sands within our plot area, despite the blowing sand, proved to be an excellent seedbed as long as they were moist for prolonged periods.

\section{Seeding in Subsequent Years}

The establishment of crested wheatgrass on the Lahontan sands by direct seeding during the winter of 1985-86 was never duplicated during the course of the study. Apparently, the exceptional moisture event of February 1986 coupled with prolonged precipitation that approximately doubled the average (Table 1) brought the site within the potential for seedling establishment of species other than Indian ricegrass.

\section{Time of Seeding}

Seeding Nezpar Indian ricegrass at 1-cm deep resulted in some seedling establishment in 3 of the 4 years that the trial was repeated (Table 3). No seedlings established in 1987-88, when only January exceeded $2 \mathrm{~cm}$ in precipitation and the total precipitation for the

Table 3. Density of Nezpar Indian ricegrass seedlings per $m$ of row by planting date for 4 years after the initial year of seeding (1985-86). Seeds planted $1 \mathrm{~cm}$ deep in seedbed. 1

\begin{tabular}{|c|c|c|c|c|c|}
\hline \multirow[b]{3}{*}{ Year } & \multicolumn{4}{|c|}{ Seedlings/m row } & \multirow{3}{*}{ Mean } \\
\hline & \multicolumn{2}{|c|}{ Fall } & \multicolumn{2}{|c|}{ Spring } & \\
\hline & Early & Late & Early & Late & \\
\hline & \multicolumn{5}{|c|}{$\ldots \ldots+$ (No. per $m$ row) $\ldots \ldots$} \\
\hline $86-87$ & $2.8 \mathrm{a}$ & $1.4 b$ & $0.4 c$ & $0 c$ & $1.2 \mathrm{y}$ \\
\hline 87-88 & $\mathbf{0}$ & 0 & 0 & 0 & $\mathbf{O z}$ \\
\hline 88-89 & $\mathbf{0}$ & 0.6 & 0.8 & 0 & $0.4 z$ \\
\hline $89-90$ & $1.3 a$ & -2 & -2 & $0.8 b$ & $1.1 \mathrm{y}$ \\
\hline
\end{tabular}

Means of seeding time (a through c) within year, and mean seedling density among years ( $y$ through $z$ ) followed by the same letter are not significantly different at the 0.05 level of probability as determined by Duncan's Multiple Range test. No letters indicate no significant differences.

2These plots were accidently destroyed before they were sampled. 
year was $7.4 \mathrm{~cm}$. Note that $1.2 \mathrm{~cm}$ of this total occurred from 1 storm in July-August (Table 1). The moisture holding capacity of the sand is only $6 \%$ (unpublished research, USDA-ARS, Reno, $\mathrm{Nev}$. If fall-winter-spring precipitation is sufficient to start seedling emergence, mid-summer moisture events may be very important in native seedling establishment (e.g., Harris 1967). In a later section we will show that it was possible to establish Indian ricegrass seedlings in 1986-87 at this site using other seeding depths and/or rates.

Seeding in the early fall gave the best seedling establishment in 2 out of the 4 years (Table 3 ). Seeding in March produced seedlings only once in 4 years. It is possible to seed these sand seedbeds the day following a moisture event, providing the immediate subsurface of the seedbed is not frozen (unpublished research, USDAARS, Reno, Nev.). The surface of the soil is so permeable, it apparently does not retain sufficient moisture to freeze.

\section{Sand as Germination Substrate for Indian Ricegrass}

The first year of direct seeding Indian ricegrass in the Lahontan sands produced from 10 to $20 \%$ seedling establishment using seed that was laboratory tested at 2 to $5 \%$ germination. The seed source was highly viable, based on tetrazolium test results reported on the seed tag, but also highly dormant, based on germination tests conducted on germination paper in petri dishes, as prescribed for standard germination test procedures (Anon. 1988). Seeds of Indian ricegrass that do not have embryo dormancy will germinate in a sand substrate when they are at an adequate moisture potential (Blank and Young 1992).

Lahontan sand from the Flanigan study site also provided an excellent germination substrate for seeds of Nezpar and Paloma Indian ricegrass in the greenhouse when the sand substrate was kept wet (Table 4). Germination did not occur on the surface of the

Table 4. Percentage emergence of seedlings of 'Nezpar' and 'Paloma' Indian ricegrass from 0 through $20 \mathrm{~cm}$ burial depth in Lahontan sand in greenhouse trials.'

\begin{tabular}{ccc}
\hline \hline Burial depth & \multicolumn{2}{c}{ Emergence } \\
\cline { 1 - 3 } cm & Nezpar & Paloma \\
\cline { 2 - 3 } 0 & $(\%)$ & $(\%)$ \\
0.1 & $0 \mathrm{f}$ & $0 \mathrm{f}$ \\
0.5 & $50 \mathrm{c}$ & $68 \mathrm{~b}$ \\
1.0 & $84 \mathrm{a}$ & $93 \mathrm{a}$ \\
2.0 & $75 \mathrm{a}$ & $91 \mathrm{a}$ \\
3.0 & $61 \mathrm{~b}$ & $88 \mathrm{a}$ \\
4.0 & $53 \mathrm{c}$ & $71 \mathrm{~b}$ \\
5.0 & $43 \mathrm{~d}$ & $61 \mathrm{bc}$ \\
8.0 & $39 \mathrm{~d}$ & $50 \mathrm{c}$ \\
10.0 & $25 \mathrm{e}$ & $27 \mathrm{~d}$ \\
13.0 & $16 \mathrm{f}$ & $15 \mathrm{e}$ \\
15.0 & $5 \mathrm{f}$ & $9 \mathrm{e}$ \\
17.0 & $5 \mathrm{f}$ & $5 \mathrm{e}$ \\
20.0 & $0 \mathrm{f}$ & of \\
\hline
\end{tabular}

'Means within columns followed by the same letter are not significantly different at the 0.05 level of probability as determined by regression equation overlap of confidence intervals (Palmquist et al. 1987).

sand substrate, but the thinnest possible burial $(1 \mathrm{~mm})$ produced much greater emergence than was reported on the seed tag for the standard germination test. Emergence decreased with increasing burial depth.

The commonly accepted rule-of-thumb for seeding grasses in rangeland seedbeds is to plant at a depth of 2-1/2 times the diameter of the seed. For Indian ricegrass this would be 2 to $4 \mathrm{~mm}$. For Lahontan sand seedbeds, seeding at a depth suggested by this rule-of-thumb, or slightly deeper, would produce optimum emergence under continuous wet conditions (Table 4). The surprising thing is that for Nezpar and Paloma some emergence came from 15 $\mathrm{cm}$ and from 39 to $50 \%$ emergence came from seeds planted $5 \mathrm{~cm}$ deep. Obviously, the relatively small Indian ricegrass caryopses produce a coleoptile with a tremendous elongation potential through sand textured substrate.

\section{Acid Scarified Seeds}

In the field the emergence of Indian ricegrass seedlings from acid scarified seeds was near zero (data not shown). Occasional seedlings were found near where these seeds were planted, but disturbance from rodent digging was so great that it was impossible to determine if the seedlings came from the planted row. The locations of acid scarified seeds were randomized in the other plantings and the rows where such seeds were planted appeared to be selectively subject to a higher level of rodent disturbance compared to adjacent rows. Plummer and Frischknecht (1952) reported that acid scarification enhances field establishment, but at the same time cautioned that acid scarified seeds may be more susceptible to seedbed diseases. McDonald (1987) discussed the many metabolic changes and interactions with fungicides associated with acid scarification of Indian ricegrass seeds. The exact reason why acid scarified seeds did not result in seedling stands at the Flanigan seeding are not known, but interest in this question is tempered by the obvious germination of nonscarified seeds of Indian ricegrass in a sand textured substrate.

\section{Depth of Seeding}

Kinsinger (1962) originally noted that natural seedlings of Indian ricegrass emerged from great depths in Lahontan sands and McAdoo et al. (1983) noted the same phenomenon for granivore cached seeds in the sands. In 4 years of 4 planting trials per year at the Lahontan sand site at Flanigan where depth of seeding was varied, the deeper planted seeds always had greater emergence than those at the shallower planting depths (Table 5) in spite of the

\section{Table 5. Seedlings of 'Nezpar' Indian ricegrass per $\mathbf{m}$ of row in relation to depth of planting. Average for planting dates per year for 1986-87 through 1989-90.1}

\begin{tabular}{|c|c|c|c|c|c|}
\hline \multirow[b]{2}{*}{ Depth } & \multicolumn{4}{|c|}{ Year of seeding } & \multirow[b]{2}{*}{ Mean } \\
\hline & $86-87$ & $87-88$ & $88-89$ & $89-90$ & \\
\hline $\mathrm{cm}$ & \multicolumn{5}{|c|}{-1 (No, per $m$ row) $-1-1}$, \\
\hline 1.0 & $1.2 \mathrm{ef}$ & of & $0.2 \mathrm{f}$ & $1.3 \mathrm{~d}-\mathrm{f}$ & $0.8 z$ \\
\hline 2.5 & 2.0de & of & 1.1ef & 1.6de & $1.2 \mathrm{yz}$ \\
\hline 5.0 & $4.0 \mathrm{~b}$ & $1.4 \mathrm{~d}-\mathrm{f}$ & 2.0de & $2.4 \mathrm{~cd}$ & $2.5 \mathrm{y}$ \\
\hline 15.0 & $6.4 \mathrm{a}$ & $2.6 \mathrm{~cd}$ & $4.5 \mathrm{~b}$ & $3.6 \mathrm{bc}$ & $4.3 \mathrm{x}$ \\
\hline
\end{tabular}

'Means followed by the same letter (a through $f$ ) and the overall means by depth ( $x$ through z) are not significantly different at the 0.05 level of probability as determined by regression equation overlap of confidence intervals (Palmquist et al. 1987).

inverse relationship found between planting depth and emergence for greenhouse emergence tests. The highest emergence observed occurred in 1986-87 at 6.4 seedlings per $m$ of row with a $15-\mathrm{cm}$ planting depth. With a seeding rate of 1 seed per $1.25 \mathrm{~cm}$ this would be $8 \%$ emergence compared to the $5 \%$ emergence that occurred from the $15-\mathrm{cm}$ planting depth in continuously wet sand in the greenhouse (Tables 4 and 5).

In interpreting these results it is important to consider that the surface of the sand is always moving due to wind eroison. Perhaps situations occur where erosion and deposition are equal and the seedlings emerge from the same depth where they were planted. The appearance of the seeded plots suggests that seedlings were emerging from shallower depths than planted due to deflation, but occasionally rows of seedlings were apparent in areas of deposition.

The most significant part of this emergence from deep planting was that deep planted seedlings emerged and established as plants in years (e.g., 1987-88) when no seedings at $1.0 \mathrm{~cm}$ deep were 
successful and only $7.4 \mathrm{~cm}$ of precipitation was received (Table 1).

The success of deep planting of Indian ricegrass seeds may be due to moisture relations in the seedbed, protection from wind deflation, or protection from granivores. Remember that under ideal moisture conditions in the greenhouse, emergence decreased with depth of seed burial. Deeply planted seeds are more difficult for rodents to locate in the sand (unpublished research, USDAARS, Reno, Nev.).

\section{Rate of Seeding}

The standard rate for seeding crested wheatgrass in the Intermountain Area has been $8 \mathrm{~kg} / \mathrm{ha}$. This rate results in 1 seed per 1.25 $\mathrm{cm}$ of row with $30 \mathrm{~cm}$ between rows. Because of the smaller seed size the comparable rate for Indian ricegrass would be $4.6 \mathrm{~kg} / \mathrm{ha}$. Obviously the environmental potential of Lahontan sand sites to support growth of perennial grasses is much lower than that of upland big sagebrush sites, and it would be logical to assume that a lower establishment rate would constitute a fully stocked stand. The standard seeding rate for crested wheatgrass merely provides a point of reference for comparison. Trials over 4 years on the Lahontan sands revealed that the maximum established seedling density was obtained with the minimum seeding rate, when seeding at a constant depth of $1.0 \mathrm{~cm}$ (Table 6). Table 6. Seedlings of 'Nezpar' Indian ricegrass per $\mathrm{m}$ of row in relation to
seeding rate. Average for 4 planting dates 1986-87 through 1989-90.
Planting depth was $1.0 \mathrm{~cm}$.' $^{\text {. }}$

\begin{tabular}{|c|c|c|c|c|c|}
\hline \multirow{2}{*}{$\begin{array}{l}\text { Planting } \\
\text { rate }\end{array}$} & \multicolumn{4}{|c|}{ Seedlings per $\mathrm{m}$ row } & \multirow[b]{2}{*}{ Mean } \\
\hline & $86-87$ & $87-88$ & $88-89$ & $89-90$ & \\
\hline \multicolumn{6}{|c|}{ seeds $/ \mathrm{cm}$ row - - } \\
\hline 0.03 & $2.6 \mathrm{ab}$ & $0.8 \mathrm{~d}$ & $2.4 \mathrm{ab}$ & $2.4 \mathrm{ab}$ & $2.2 \mathrm{x}$ \\
\hline 0.1 & $2.3 \mathrm{~b}$ & $0.2 \mathrm{de}$ & $1.3 \mathrm{c}$ & $2.2 \mathrm{~b}$ & $1.5 \mathrm{z}$ \\
\hline 0.4 & $2.0 \mathrm{~b}$ & $0 \mathrm{e}$ & $0.8 \mathrm{~d}$ & $2.0 \mathrm{~b}$ & $1.2 z$ \\
\hline 0.8 & $2.1 \mathrm{a}$ & Oh & $1.1 \mathrm{~d}$ & $1.8 \mathrm{bc}$ & $1.3 \mathrm{z}$ \\
\hline
\end{tabular}

${ }^{1}$ Means followed by the same letter (a through $h$ ) and overall means ( $x$ through $z$ ) are not significantly different at the 0.05 level of probability as determined by regression equation overlap of confidence intervals (Palmquist et al. 1987).

Seeding at the ultra-low rate of 0.03 seeds per $m$ of row resulted in an average of $73 \%$ of the planted seeds emerging and becoming established as plants (Table 6). For the maximum seeding rate only $2 \%$ of the seeds planted resulted in seedling establishment. In $1987-88$, seeding at reduced rates resulted in some seedling establishment when normal seeding rates failed to establish any seedlings.

The success of ultra-low seeding rates has immediate economic significance. If we assume a cost for Indian ricegrass seed of $\$ 22.00 / \mathrm{kg}$, the seeding rate of $8 \mathrm{~kg} / \mathrm{ha}$ would have a seed cost of $\$ 176.00 /$ ha. The cost of seed for the ultra-low rate would be $\$ 6.65 /$ ha. The cost of Indian ricegrass seed has fluctuated from $\$ 10.00$ to $\$ 25.00 / \mathrm{kg}$, but the proportional savings, even at reduced prices, is significant.

The success of the ultra-low seeding rate may be due to intraspecific competition and/or granivore predation. As was potentially the case with deep planting of Indian ricegrass, the ultra-low seeding rate may make it more difficult for rodents to locate and recover artificially planted seeds.

In interpreting these results it is important to realize that the area burned outside of our experimental plots underwent dynamic natural seedling recruitment of Indian ricegrass in the years subsequent to the wildfire. There was a small seedbank of Indian ricegrass seeds in the sands as predicted by past research (Young et al. 1983). Seedling establishment from this seedbank, followed by seed production and rodent assisted seed dispersal, apparently were important aspects of this dynamic seedling recruitment. High rodent densities and a dramatic increase in rodent species diversity occurred with the recruitment dynamics of Indian ricegrass (unpublished research, USDA-ARS, Reno, Nev.). This meant that our experimental plots were potentially subject to heavy granivore predation. As mentioned previously, selective predation on the most apparent seeds (i.e., those at shallow planting depths and higher planting densities) may explain some of our seedling emergence results.

\section{Drill Seeding}

Deep seeding of Indian ricegrass at ultra-low rates on the Bird Flat Ranch using a drill with a fluted coulter-double-disk opener resulted in a seedling stand that averaged 4.1 established seedlings per $m$ of row over a 2-ha seeding. It was difficult to obtain this ultra-low rate through the drill which used a fluted shaft to meter seeds. The first true leaf on these seedlings was usually cut at the soil surface by wind driven sand. A second leaf emerged with apparent minimum seedling mortality. We never observed this abrasion of seedlings at the Flanigan site, where the sand particles are rounded.

This study clearly shows that sand sheets in the Lahontan basin of northern Nevada can be seeded to Indian ricegrass. The typical low germination of Indian ricegrass seeds from standard laboratory tests is misleading when the seeds are seeded on sand textured seedbeds. Low rates of seeding and deep seedings both appear to be beneficial for seedling establishment in the sand seedbeds in the field.

\section{Literature Cited}

Anon. 1941. Climate and man. Yearbook of Agriculture. USDA, Gov. Print. Off., Washington, D.C.

Anon. 1978. 'Paloma' Indian ricegrass. New Mexico State Univ. Coop. Ext. Ser. Cir. 474.

Anon. 1988. Rules for testing seed. Assoc. Official Seed. Anal. J. Seed Tech. 12:55.

Billings, W.D. 1949. The shadscale vegetation zone of Nevada and eastern California in relation to climate and soils. Amer. Midl. Natur. 42:87-109.

Blank, R.R. and J.A. Young. 1992. Influence of matric potential and substrate characteristics on germination of Nezpar Indian ricegrass. J. Range Manage. 45:205-209.

Booth, D.T., C.G. Howard, and C.E. Mowry. 1980. 'Nezpar' Indian ricegrass: Description, justification for release, and recommendations for use. Rangelands 2:53-54.

Clark, D.C. and L.N. Bass. 1970. Germination experiments with seeds of Indian ricegrass [Oryzopsis hymenoides (Roem. \& Schult.) Ricker] Proc. Assoc. Official Seed Anal. 60:226-239.

Fendall, R.K. 1964. An investigation into the site and seed dormancy in Stipa viridula and Oryzopsis hymenoides. Diss. Abstr. 26:3569-3570.

Harris, G.A. 1967. Some competition relationships between Agropyron spicatum and Bromus tectorum. Ecol. Monogr. 37:89-111.

Hitchcock, A.S. 1950. Manual of grasses of the United States. USDA. Gov. Print., Washington, D.C.

Huntamer, M.Z. 1934. Dormancy and delayed germination of Oryzopsis hymenoides. M.S. Thesis. State College of Washington, Pullman.

Kinsinger, F.E. 1962. The relationship between depth of planting and maximum foliage height of seedlings of Indian ricegrass. J. Range Manage. 15:10-13.

McAdoo, J.K., C.C. Evans, B.A. Roundy, J.A. Young, and R.A. Evans. 1983. Influence of heteromyid rodents on Oryzopsis hymenoides germination. J. Range Manage. 36:61-64.

McDonald, M.D. Jr. 1987. The release of multiple dormancy and metabolic response to scarification in Indian ricegrass seeds. p. 21-33. In: G.W. Frasier and R.A. Evans (ed.) Proc. Symp.: Seed and Seedbed Ecology of Rangeland Plants. ARS, USDA. Tucson, Ariz.

McDonald, M.B., Jr. 1976. Improving the germination of Indian riccgrass seeds. J. Seed Tech. 1:44-54.

McDonald, M.B., Jr. and A.A. Khan. 1977. Factors determining germination of Indian ricegrass seeds. Agron. J. 64:558-563. 
McDonald, M.B., Jr., and A.A. Khan. 1978. Metabolic changes in Indian ricegrass seeds in relation to coat-imposed and embryonal dormancy. Agron. J. 70:829-835.

MeDonald, M.B., Jr., and A.A. Khan. 1983. Acid scarification and protein synthesis during seed germination. Agron. J. 75:111-114.

Morrison, R.B. 1964. Lake Lahontan: Geology of the southern Carson Desert, Nevada. U.S. Geol. Surv. Prof. Paper 401. Washington, D.C.

Palmquist, D.E., R.A. Evans, and J.A. Young. 1987. Comparative analysis of temperature-germination response surfaces. p. 97-103. In: G.W. Frasier and R.A. Evans. (ed.) Proc. Symp.: Seed and Seedbed Ecology of Rangeland Plants. ARS, USDA, Tucson, Ariz.

Plummer, A.P., and N.C. Frischknecht. 1952. Increasing field stands of Indian ricegrass. Agron. J. 44:285-287.

Robertson, J.H. 1976. The autecology of Oryzopsis hymenoides. Mentzelia $1: 18-21,25-27$.

Rogler, G.A. 1960. Relation of seed dormancy of Indian ricegrass [Oryzopsis hymenoides (Roem. \& Schult.) Ricker] to age and treatment. Agron. J. 52:470-473.

Russell, I.C. 1885. Geological history of Lake Lahontan. US Geol. Surv. Washington, D.C.

Shaw, N.L. 1976. An investigation of factors affecting the germination of Oryzopsis hymenoides. M.S. Thesis. Idaho State Univ., Pocatella.

Stoddart, L.A., and K.J. Wilkinson. 1938. Inducing germination of Oryzopsis hymenoides for range reseeding. J. Amer. Soc. Agron. 30:763-768.

Toole, V.K. 1940. The germination of seeds of Oryzopsis hymenoides. Agron. J. 32:33-41.
Young, J.A., and R.A. Evans. 1984. Germination of seeds of 'Paloma' and 'Nezpar' Indian ricegrass. J. Range Manage. 37:19-21.

Young, J.A., and D. McKenzie. 1982. Rangeland drill. Rangelands $4: 248-251$.

Young, J.A., and Frosty Tipton. 1989. Invasion of cheatgrass into environments of the Lahontan Basin. p. 37-41. In: Symp. Cheatgrass Invasion, Shrub Die-off, and Other Aspects of Shrub Biology and Management. (compilers) E.D. McArthur, E.M. Romney, S.D. Smith, and P.T. Tueller. Gen. Tech. Rep. 276. Forest Serv., USDA, Ogden, Utah.

Young, J.A., and B.A. Sparks. 1985. Cattle in the cold desert. Utah State Univ. Press, Logan.

Young, J.A., R.A. Evans, and D.A. Easi. 1985. Enhancing germination of Indian ricegrass seeds with sulfuric acid. Agron. J. 77:203-206.

Young, J.A., R.A. Evans, and R.E. Eckert, Jr. 1969. Emergence of medusahead and other grasses from four seeding depths. Weed Sci. 17:376-379.

Young, J.A., R.A. Evans, and B.A. Roundy. 1983. Quantity and germinability of Oryzopsis hymenoides seed in Lahontan sand. J. Range Manage. 36:82-86.

Young, J.A., R.A. Evans, and P.T. Tueller. 1976. Great Basin plant communities-pristine and grazed. p. 187-215. In: Holocene Environmental Change in the Great Basin. Res. Paper 6. Nevada Arch. Survey, Reno.

Zemetra, R.S., Cynthia Havstad, and R.L. Cuany. 1983. Reducing seed dormancy in Indian ricegrass (Oryzopsis hymenoides). J. Range Manage. $36: 239-241$. 